Obituaries

Michael Fordham, formerly Director Training to Child Analysis, Society Analytical Psychology, London.

Michael Fordham, who died on April 141995 at the age of 89 , was a controversial figure in the world of Jungian analysis. He saw himself as an innovator who corrected deficiencies in Jung's theoretical legacy by laying stress on the importance of transference and countertransference interactions between analyst and patient and on the analysis of infantile wishes, responses and defences as critical developmental influences in child, adolescent and adult psychology. Pursuing this line, he advocated a rapprochement between Jungian theories and those of the neo-Freudian, Kleinian and object relations schools of psychology. For these innovations he was applauded by some but excoriated by others who accused him of leading a regression to Freud's couch-oriented, reductive techniques and of betraying the teleological-symbolic approach to personal growth and development at the heart of classical Jungian practice.

Coming from an ancient clan of East Anglian farmers, Fordham was educated at Gresham's School, Holt (where he was a contemporary of W. H. Auden and the embarrassed subject of a poem by him) and Trinity College, Cambridge. He studied medicine at St Bartholomew's Hospital and would have become a neurologist had not an early marriage (to Molly Swaby at 23) combined with shortage of money to drive him into an appointment as a junior medical officer at Long Grove Hospital, Epsom. There he found the smell of paraldehyde and the custodial, quasi-military regime uncongenial, but the undemanding routine of mental hospital life gave him time to read and to play cricket, at which he excelled. On the suggestion of Alan Moberley, a medical friend in London, himself destined to become a psychotherapist, Fordham began reading Jung. At first sceptical about Jung's theory of the collective unconscious, he nevertheless decided to put it to the test. One of his Long Grove patients believed himself to be 'the devil's disciple.' The evil which had him in its power was rotting away his internal organs and his eventual death, he declared, would take away the sins of humanity. If Jung was right, Fordham reasoned, then this unfortunate patient was in the grip of some scapegoat myth and he should be able to find the details in Frazer's The Golden Bough. Sure enough, the themes apparent in the patient's delusions were all there.

Having fallen out with his physician superintendent, Dr F. G. L. Barnes, and with some of his colleagues (who included Dr Alexander Walk), and wishing to escape from the deadening constraints of hospital routine, Fordham applied for and obtained a Fellowship in Child Psychiatry at The London Child Guidance Clinic. He also went into analysis with Dr Godwin Baynes, one of the first of Jung's pupils to practise in London. This analysis, which lasted over seven years, consisted largely of dream interpretation. 'active imagination' and the free drawing and painting of unconsciously produced images. Baynes showed this material to Jung and eventually published it in his mammoth Mythology of the Soul. In Baynes's view, the decisive event in Fordham's history was the death of his mother when he was twelve. This, combined with the personality of his detached, intellectually erratic father, who devoted himself to Fabian enthusiasms and to the arts and crafts movement rather than to the emotional needs of his bereft son, resulted in a one-sided, inhibited development which Baynes did not hesitate to describe as schizoid: 'Charm of manner made him accessible,' observed Baynes, 'but psychologically he lived in chilly isolation.'

Although, as he himself acknowledged, Fordham had 'no special liking for children', he nevertheless found his clinical work interesting. At first he approached the behaviour disorders and neuroses of his patients as a function of unconscious conflicts in their parents. Such an approach was in accordance with Jung's view that child analysis could achieve little and could do actual harm if the parents' problems were left untreated. As he gained experience, however, Fordham felt the need to intervene more actively in his work with children whose 
psyche he came to see as less a passive reflection of parental influences and more a dynamic and developing entity with its own priorities and agendas. Adapting some features of his own analysis with Baynes, he encouraged children to recount their dreams, draw and paint their inner images, and take pleasure in fairy tales. As a result of this imaginative approach, he began to earn a reputation for the treatment of severely disturbed children.

Feeling the need for more extensive psychological understanding, Fordham went, on Baynes's suggestion, to Zurich to seek an analytic training with Jung. When he presented himself in Zurich, however, he was told by Jung that the Swiss authorities, fearing a massive influx of refugees, had made it virtually impossible for foreigners to work there. Disappointed and angry that Jung had not warned him of this beforehand, Fordham returned to England to resume his analysis with Baynes and his work in child guidance. It was then that he turned to the work of Melanie Klein. He read The Psychoanalysis of Children with amazement and emotional shock.' He was particuarly impressed by Klein's use of play as a means of communication, by her understanding of the basic role of fantasy in a child's development, and by her insistence that children invariably develop a transference to their therapist. The importance of transference for the outcome of child analysis increasingly preoccupied himand made him critical of Baynes's handling of his own analysis. Moreover, he had started an extra-marital affair, which Baynes encouraged as a means to making a conscious relationship with his anima. Fordham later blamed him for this: 'his support contributed to the undermining of my marriage.' He began to feel trapped in the analysis. Because he could not afford to pay fees, Baynes agreed to accept Fordham's analytical material as payment, for inclusion in Mythology of the Soul. 'One disadvantage of this,' commented Fordham, was that I felt obliged to keep on producing pictures to keep up payments!' As his relationship with his wife deteriorated, he became convinced that it was due to the absence of transference analysis in his work with Baynes.

Uncertain what to do, he sought advice from Jung who told him to stop the analysis. Fordham followed Jung's advice, acknowledging, nevertheless, that his work with Baynes had been far from unproductive. It had released his imaginative powers, convinced him of the reality of unconscious processes, and inspired him to go his own way in seeking his own truth.

For a while he analysed with another Jungian, Hilde Kirsch, to whom he felt powerfully attracted, but he thought she also ducked the erotic nature of his transference and failed in her duty to him by declining to analyse it. Since, in his view, neither analyst knew how to analyse his childhood or understand how to work with transference, he felt impelled to make these two aspects of analysis his particular concern.

His marriage to Molly Swaby, contracted in 1928, came to an end when in the late 30 s Fordham fell in love with Frieda Hoyle, a social worker with whom he went to Nottingham to start up a child guidance team under the auspices of the local medical officer of health. Fordham divorced Molly in 1940 and married Frieda the same year. Frieda was herself to become an analyst and the author of one of the best early introductions to Jung's psychology. Their marriage lasted until her death in 1988. Fordham said that he found with her the sort of love he had had for his mother. They had no children, though Frieda had two sons by a previous marriage.

In 1942 Fordham was appointed to a consultant post created to help evacuee children in Nottinghamshire who had not been able to settle in billets. This was a further simulus to extend Jungian theory into childhood. Since his charges had been removed from their homes, their parents were unavailable for treatment and Fordham had, faute de miewx, to work on their intrapsychic representatives through the medium of the transference. On the basis of this work, he published his first book. The Life of Childhood, in 1944. He argued that the self, in the Jungian sense, was an active factor in child development and rejected the idea that disturbed children could only be treated indirectly. Children showed a remarkable capacity to overcome their difficulties if given sympathetic understanding and support.

At the end of the war, Fordham, together with six other London Jungians (Gerhard Adler, Culver Barker, Erna Rosenbaum, Philip Metman, Lola Paulsen and Robert Moody) launched the Society of Analytical Psychology, which was to provide a training in both child and adult analysis. It is significant that Fordham insisted that the society should be called the Society of Analytical Psychology (SAP) and not the C. G. 
Jung Institute. He feared there was a danger that Jungian psychology was turning into a personality cult and he held that the London society should exist to serve the development of analytical psychology as a science rather than to celebrate and perpetuate the reputation of its founder. Also, on Fordham's insistence, the training programme required all candidates to devote time to systematic observation of infants and young children. The SAP has continued to flourish and is now one of the largest and most influential Jungian societies in the world.

In 1955, Fordham became the first editor of the Journal of Analytical Society, a post which he held for 15 years. This is published four times a year and continues to produce clinical and theoretical papers relating to the practice of Jungian psychology. It has come to enjoy a worldwide reputation.

The main debt owed to him by the Jungian community throughout the English speaking world is for his co-editorship (with Gerhard Adler and Herbert Read) of R. F. C. Hull's translation of the 19 volumes of The Collected Works of C. G. Jung. As chief editor, Fordham, was responsible for the way in which the material was organised for publication: the volumes were arranged not in chronological order but according to subject matter, starting with Jung's word association studies and ending with his erudite investigations into religion and alchemy. This ambitious project was largely financed by the Bollingen Foundation, set up in 1945 in New York by the philanthropists Paul and Mary Mellon, both devotees of Jung. In addition to this editorial work, which was to occupy him for over 25 years, Fordham authored numerous articles and reviews and published eight books of his own.

To those wishing to train as analytical psychologists in England, Fordham's amalgam of Jungian and Kleinian theories, augmented by his own observations and formulations concerning psychological development in infancy and childhood, proved persuasively seductive. By enshrining these principles, the SAP has influenced the design and content of training programmes as well as the practise of Jungian psychology not only in Britain but also in the USA.

However, these developments have not always met with unqualified acclaim. In the '50s, a growing number of critics complained that Fordham's theoretical revisions had contributed to a crisis of identity among members of the SAP who began to question whether they could describe themselves as Jungian analysts at all. Gerhard Adler, one of Fordham's co-editors of The Collected Works, felt so strongly that Fordham had deviated from the original spirit of Jung's work, that, together with other analysts trained in Zurich (Culver Barker, Erna Rosenbaum, Vera von der Heydt, and Adler's wife Hella) he set up an 'Alternative Training' within the SAP. The conflict which ensued between these two theoretical orientations proved too great for them to be contained within the same organisation and the 'orthodox' Zurich analysts eventually seceded to form their own Association of Jungian Analysts. This was itself to give rise to another 'classical' Zurich oriented group, the Independent Group of Analytical Psychologists. The British Association of Psychotherapists has also developed its own Junglan analytical training along lines similar to those of the SAP. There are those who maintain that the existence of no less than four Junglan training groups in London is due to Fordham's reassimilation of Jungian psychology and his attempt to put a neo-Kleinian stamp on it. However, it is in the nature of analytic groups, of whatever school, to split on doctrinal grounds and there is justice in Fordham's argument that analytical practices, if they are to gain wide acquiescence, should be based on empirical observation.

Whether his revisions of Jungian theory will prove to be of lasting influence may, however, be open to doubt. The epistemological bases of Freudian and Kleinian concepts, which he held in such high esteem, have recently come under devastating attack, while Jung's theories of archetypes, dream production, and the curative powers of the imagination have achieved much empirical verification and a growing clinical acceptance, not least in the new science of evolutionary psychiatry. Fordham sometimes wrote as if he were the only analyst to hold that the child was no tabula rasa but an intact individual full of innate human potential, who influenced and moulded the environment as much as the environment influenced and moulded her or him. In fact, this position was proposed and developed to much more systematic and influential effect by John Bowlby, Mary Ainsworth, and their co-workers, whose carefully framed hypotheses concerning child development and mother-infant attachment bonds gave rise to much valuable 
research and improved therapeutic initiatives throughout the world. Yet, in his published work, Fordham omitted all mention of Bowlby and the important consequences of his work.

Whatever judgement may finally emerge as to Fordham's status, history will not deny him the accolade of being one of the very last analysts in the present century who, by the force of his own personality, was able to influence the course of analytic theory and practice.

ANTHONY STEVENS

Ernest John Eurfyl Jones, formerly Consultant Psychiatrist, St David's Hospital, Carmarthen, Dyfed, Wales.

Dr Ernest John Eurfyl Jones, died on 24 April 1995. He was born in Merthyr Tydfil in 1924 but grew up in Llandiloes, where his father was a Presbyterian minister. He was educated in Llandovery College, Lincoln College, Oxford and the Welsh National School of Medicine. He graduated BM.BCh(Oxon) in 1948. Having returned to Oxford for postgraduate training in Psychiatry, he was appointed Consultant Psychiatrist at St David's Hospital, Carmarthen, in 1955. He later became Deputy Physician Superintendent, a post which he held with great distinction until his retirement in 1980 . He was a Fellow of the Royal College of Psychiatrists and a former chairman of the Welsh Psychiatric Society.

A bare outline of his career tells one very little about this remarkable man. His was one of the most brilliant minds I have encountered, but he was also one of the most colourful people I have known. Lively and resourceful (he used to recount with pride how, as a medical student, he at one time financed his studies by working as a second-hand car salesman in City Road, Cardiff), he always faced challenges head on. Extremely articulate and a brilliant public speaker in both English and Welsh, he was combative in argument and he could be blistering in his criticism of anything which he perceived as cant or humbug, cowardly or unjust. Yet, although he was certainly not one to suffer fools gladly, he was warm-hearted and showed immense kindness and sympathy to anyone who turned to him for help.
He was one of the pioneering activists of Plaid Cymru in the Carmarthen constituency, whose leadership and organisation helped pave the way for Gwynfor Evans's success in 1966. He would, I think, have stood every chance of achieving high office had he chosen to pursue his political interests within the socalled mainstream of British politics. He also did a great deal of broadcasting about medical topics in Welsh at a time when few others had attempted to do so.

Throughout his professional career he was involved in providing a psychiatric service in Llanelli and Ammanford but he was also a pioneer in developing community care in this locality. He was the inspiration behind the move to rehabilitate people who had spent many years in St David's Hospital, rehousing them in group homes and other locations in the community. It was also thanks to his efforts that Carmarthen MIND Association was founded more than 20 years ago.

Forced to retire early by the ill-health which blighted his life from then on, one product of his retirement was a penetrating extended essay in Welsh on Carl Gustav Jung which was published in the Meddwl Modern Series in 1985. With his wide interests, penetrating mind and remarkable memory he would, I am sure, have produced a great deal more during his retirement years had his health permitted.

Many will share my view that it was a privilege to have known and worked with such a remarkable man and will wish to extend their deepest sympathy to Betty, Siôn and Siân and their families.

Huw EDWARDS

\section{The deaths of the following have also been reported:}

Nagwa Mustafa Mohamed Ali, Senior House Officer, c/o Mustafa Mahmed Ali, P.O. Box 6192, Khartoum, Sudan

John Hanson Demaine, Consultant Psychiatrist, Stanley Royd Hospital, Wakefield, W. Yorks. 1 Ashburnham Grove, Bradford, W. Yorks

JAMES LAURENCE DUFFY, Department of Psychiatry, Richmond General Hospital, 7000 Westminster Highway, Richmond, British Columbia, Canada 